\title{
Climate Smart Production, Gross Income, and Downstream Risk Characterization of Rice Farmers in Ghana
}

\author{
Shaibu Baanni Azumah
}

Global Shea Alliance. Accra, Ghana |DAAD climapAfrica Postdoctoral fellow. University for Development Studies. P. O. Box TL 1882. Tamale, Ghana. Email: raszumah1983@gmail.com ORCID: https://orcid.org/0000-0001-9046-5079)

Abraham Zakaria

Asdev Consult. P. O. Box TL 407. Tamale, Ghana. Email: lamhabram@gmail.com ORCID: https://orcid.org/0000-0002-1522-7510)

Rosaine N. Yegbemey

DAAD climapAfrica Postdoc Fellow. Department of Rural Economy and Sociology, Faculty of Agronomy. University of Parakou. Benin. Email: ynerice@gmail.com ORCID: https://orcid.org/0000-0003-2051-0289)

Philips A. Apalogta

Department of Development Studies, Faculty of Integrated Development Studies. SD. Dombo University of Business and Integrated Development Studies. Ghana

Vishal Dagar

Assistant Professor of Economics (Visiting) at Amity School of Economics, Amity University Uttar Pradesh (AUUP), NOIDA - 201 313, India. Email: dagarvisha199@gmail.com

ORCID: https://orcid.org/0000-0001-5032-1783

Abass Mahama (Corresponding Author)

Policy, Planning, Monitoring and Evaluation Directorate, Ministry of Food and Agriculture, Accra, Ghana. Email: mahama.abass@ymail.com

ORCID: https://orcid.org/0000-0002-8533-5787

Received: December 15, 2021 Accepted: January 16, 2022 Published: January 22, 2022

doi:10.5296/jas.v10i2.19495 URL: https://doi.org/10.5296/jas.v10i2.19495 


\section{Abstract}

Purpose - Climate smart production is a potential solution to the negative effects of the changing climatic conditions on agricultural production systems in Africa in general, and particularly in Ghana.

Design/methodology/approach - In this study, we employed a Multinomial Treatment Effect (MTE) regression model, using primary data collected from 543 rice farmers in Ghana, to examine the drivers of single and joint adoption of selected Climate Smart Agriculture (CSA) practices (i.e., improved rice varieties and irrigation). The study further explored the implications of the adoption of CSA practices on gross income and reduction of risk (skewness of rice yield) faced by rice farmers.

Findings - The empirical results show that education, experience, and extension service significantly influenced joint adoption of irrigation and improved rice varieties positively; while livestock ownership, farm size, and social capital significantly influenced joint adoption negatively. In addition, single adoption of improved rice varieties and irrigation as well as joint adoption significantly influenced rice farmers' income and risk exposure positively. Education, rice commercialization, experience, and social capital also bore significant positive relationships with income and rice farmers' risk exposure, while quantity of fertilizer applied per acre and farm size significantly influenced income and rice farmers' risk exposure negatively.

Research limitations/implications - There exists a pool of literature on climate smart agriculture technology adoption among rice farmers. However, these studies do not highlight the nexus between the adoption of climate smart technology and its implications on gross income and risk characterization of rice farmers.

Practical implications - The adoption of climate smart production mechanisms like the use of improved rice varieties and irrigation should be encouraged among rice farmers since they have the potential to increase gross income while reducing farmers' exposure to risk in the face of climate change.

Social implications - Policymakers and project implementers should give priority to socioeconomic and institutional factors that promote the adoption of CSA practices among rice farmers in programming of development interventions.

Originality/value - The study examined the factors that drive rice farmers to adopt improved rice varieties and irrigation, as well as joint adoption of improved rice varieties + irrigation in northern Ghana.

Keywords: climate smart agriculture, downstream risk exposure, Ghana, gross income, multinomial treatment effect, rice farmers

\section{Introduction}

CSA practices are broadly acknowledged as promising climate change adaptation strategies to avert the effects of climate change on agricultural production systems. Despite this importance, 
the adoption rates of CSA practices such as the use of improved varieties and irrigation remain low, especially in a developing country like Ghana (Kangogo et al., 2021). Additionally, there is limited evidence on the drivers and economic benefits of these CSA in rice production in developing countries. Against this backdrop, this study analysed the key socio-economic drivers and the economic return of the adoption of improved rice varieties and irrigation which have been found to be critical in climate smart production in Ghana. The study contributes to existing literature in two ways. First, the study examined the factors that drive rice farmers to adopt improved rice varieties and irrigation as well as joint adoption (improved rice varieties and irrigation). Second, the study highlights the nexus between the adoption of CSA practices and its implications on gross income and reduction of downstream risk for rice farmers in the face of climate change.

Rice is a global commodity with an ever-increasing demand both in the local and internal markets (Durand-Morat \& Chavez, 2020). The world cannot achieve Sustainable Development Goals One (zero poverty) and Two (zero hunger) and their targets without rice production to meet the global consumption needs. It is a primacy that the production of rice is of great benefits in meeting the food security needs of households and as a source of farm income (Jumiyati, 2021). In Ghana, rice is produced as an important staple next to maize. The contribution of rice to the national food basket of Ghana has experienced growth of 10 percent in the period of 2008 to 2019 (IFPRI, 2020). Although the production of paddy rice has increased, the consumption of rice still falls below the domestic production levels, with over 50 percent of domestic consumption demand augmented by imports (MoFA, 2018).

The rice sector in Ghana has received a glaring focus and attention from both state institution as well as the non-state agricultural institutions since 1970s, with numerous policies and programmes geared towards enhancement in production and productivity (Emmanuel et al., 2018; Abdulai \& Huffman, 2010; Donkor et al., 2013). Some of these policies include the National Rice Development Strategy, Food and Agricultural Sector Development Policy I and II, New Rice for Africa (NERICA) and the recent Planting for Food and Job Policy launched in 2018. All these policies and programmes are geared towards sustainable domestic rice production to improve food security and farm households' income.

Climate change is a global threat to sustainable agricultural production and food systems. It makes agricultural land and farmers vulnerable, thereby, worsening the already existing food insecurity situations in Africa and deepening the poverty level of the already marginalized farm households. According to Arunrat et al. (2017), climate change and variability is an embodiment of rising temperature, variations in the intensity and patterns of precipitation and increased in the incidence of extreme events such as droughts and floods. The impact of climate change on rice production has been a concern to many scientists (Van Oart and Zwart, 2018; Lv et al., 2018; Langerwisch et al., 2017). Boonwichai et al. (2018) indicated that crop-water productivity and crop-water requirement in addition to rice yield would be affected by changing climate and environment. Other researchers such as De silva et al. (2017) and Wongchalee et al. (2015) indicated that high temperatures and decline in rainfall as well as sporadic rainfall have potential adverse negative effects on crop yields, specifically rice which is a water-loving crop. It has been estimated that by close of the year 2050, the yield of rice will 
decline by 10-15 percent with a resultant increase in rice price by 32-37 percent (IFPRI, 2014). This highlights the need for stakeholders including rice farmers in the rice value chain to design and adopt Climate Smart Agricultural (CSA) practices.

The concept of CSA production is fast evolving and gaining prominence in the $21^{\text {st }}$ century as it is the panacea to sustainable agriculture production and food systems. CSA is a system of production that encompasses three distinct characteristics which includes sustainable and equitable improvement in agricultural productivity and income levels, enhancement in adaptation capacity and resilience enhancement, and the mitigation of greenhouse gas emission (Lipper et al., 2014; De Pinto et al., 2020). Due to the significant nature of CSA for sustainable food systems, it stems in the global green development agenda (World Bank 2011: Palombi \& Sessa, 2013) for climate action measures. Therefore, policymakers are mostly interested in feasible implementation of CSA even if farmers adopt or fail to adopt it. CSA has the potential to eliminate/reduce the adverse effect of climate change on agri-food systems while enhancing food security and sustainable livelihoods among poor resource farm households. Researchers have raised arguments that the operationalization of some aspects of the CSA production concepts is quite uncertain as the three elements of CSA (productivity, adaptation, and mitigation), as well as the trade-offs between them, are determined by location-specific characteristics (Below et al., 2012; FAO, 2018). It has also been argued that social justice is prime in the adoption of CSA and sustainable agricultural production and productivity (Taylor, 2018).

In rice production, there is an array of CSA technologies that can be used in dealing with climate change-induced challenges (Teklewold et al., 2017). However, numerous factors as related to education, culture, resources mobilization capacities, and farm characteristics affect the adoption capacities of farmers. CSA technologies being identified includes, use of healthy (improved) young seedlings, transplanting of single seedlings, early weed management, management of soil water, soil aeration, crop-switching, crop rotation, intercropping, adjusting planting time, irrigation, and the application of manure and compost (World Bank, FAO \& IFAD, 2015). However, adoption levels and drivers of adoption of these CSAs vary across the globe due to farmers' characterizations and access to production resources.

This study focuses on two main CSA production techniques; use of improved seeds and irrigation as they have become a prime target for policymakers to minimise the effect of climate change on food systems. Thompson and Scones (2011) noted that improved rice seed is one of the mechanisms of productivity enhancement which has a resultant positive effect on enhancing the food security status and income levels of farm households. Similarly, other studies (Zhang et al., 2017; Chandio et al., 2018; Arouna et al., 2017; Awotide et al., 2016) highlights that the adoption of improved rice varieties have multiple folds positive impacts on enhancing the productivity among farmers. More so, the importance of irrigation, as a CSA production technology is highlighted in the works of many researchers such as Nonvinde (2017) who opines that rice production under an irrigation system could improve incomes of farm households due to production of food crops at different regimes per year. Furthermore, Bidzakin (2018) argued that farmers operating under irrigation systems are more technically efficient in production relative to their counterparts operating under the rain-fed system. 
There exists a pool of literature on CSA technology adoption among rice farmers (e.g., Abdulai \& Huffman, 2014; Zakaria et al., 2020; Anuga et al., 2019). However, these studies do not highlight the nexus between the adoption of CSA and its implications on gross income and risk characterization of rice farmers. Against this backdrop, the study sought to examine the factors driving rice farmers to adopt improved rice varieties and irrigation as well as joint adoption (improved rice varieties + irrigation) in northern Ghana. Also, the study further explored the effect of individual adoption of the CSA technologies on gross income and reduction of downstream risk of rice farmers in Ghana.

\section{Methodology}

\subsection{The Study Area, Data and Sampling}

This study was conducted in the Northern, Savannah, and Upper East regions of Ghana. The vegetation and agricultural land for these regions are suitable for rice production, making them to be among the top rice production areas in the country. However, rice farmers have been vulnerable to climate change, therefore reducing rice production potentials and increasing rice production risk in the areas. Primary information was solicited from rice farmers using semi-structured questionnaires.

A three-stage sampling procedure was used to select the study areas and rice farmers for the study. Purposive sampling method was first used to select the three regions in the North of Ghana known for high production volumes of paddy rice. Again, purposive sampling method was used in the second stage to select ten (10) administrative districts in the three regions; Upper East Region (Kassena-Nankana, Bolgatanga, Bongo, Bulsa-North), Northern Region (Karaga, Savelugu, Gusheigu, Tolon and Kumbungu), and Savanna Region (Central Gonja) (See figure 1). The population of rice farmers in these three regions are estimated to be 296,489. Based on this information, Slovin's (1960) sample size determination was used to obtain 543 rice farmers for the study. In the last stage, a systematic sampling procedure was employed to select rice farm households.

To ensure the integrity and quality of the data, the consent of rice farmers was sought before the administration of the questionnaire by well-trained Research Assistants. The Cronbach Alpha was used to test for the reliability of the data instrument. A Cronbach Alpha value of 0.81 was obtain, consistent with Malley (2003) and DeVellis (2012) that a good Cronbach Alpha value lies between 0.80 and 0.90. Data collection was conducted in the 2017/2018 agricultural production calendar within the period of November 2017 to February 2018.

\subsection{Analytical Framework and Econometric Model}

The aim of this study was to examine the determining factors of rice farmers' adoption of CSAs and its implications on rice gross income and downstream risk exposure (rice yield skewness). Following the works of Di Falco and Chavas (2009), Kassie et al. (2014), and Issahaku and Abdulai (2019), rice yield skewness distribution was computed. The calculation was done by approximately using the third central moment of rice yield distribution. Rice yield skewness is a best measure of rice farm performance with uncertainty associated with the changing climate. This is because rice yield skewness captures the exposure to downside (downstream) risk (Di 
Falco \& Chavas, 2009, Issahaku \& Abdulai, 2019).

There are series of sequence of computing the moments of rice yield skewness which represents the risk exposure. That is how rice farmers might fail in achieving desired rice yield due to climate change. First, the rice yield was regressed on rice production inputs and other socioeconomic factors, using Ordinary Least Square (OLS) estimation criteria. Second, the residuals for rice yield were predicted and retrieved. The third moment was computed by raising the residuals to the third-power as it has been done by Di Falco and Chavas, (2009) and Issahaku and Abdulai (2019). The computed value for the third moment of rice yield was used as an outcome (response) variable in the Multinomial Treatment Effect (MTE) model to estimate the effects of individuals and joint adoption of CSA on rice gross income and risk exposure.

Estimation of impact of adoption of CSA among rice farmers have serious difficulties due to non-randomness or non-experimental nature of rice farmers' decision to adopt. The difficulty of the non-experimental nature of rice farmers' adoption decision is due to selectivity bias issues. There are several methodological approaches to deal with this selectivity issue when conducting research. Such methods include propensity score matching (PSM), Heckman Two stage, endogenous switching regression, Multinomial Treatment Effect (MTE) methods among others. When the response (dependent) variable is categorical, the best model to use in order to correct the selectivity issue is the MTE (Deb \& Trivedi, 2006a).

The MTE is a two-stage estimation technique where the first stage function is an Ordinary Least Square method and the second stage takes a multinomial distribution function. Mentioning that the selection into treatment groups based on an observable characteristics of rice farmers, Rosenbaum and Rubin (1983) and recent scholars, (Imbens \& Wooldridge, 2009; Cattaneo, 2010) have demonstrated that individual rice farmers belong to different treatment groups but have similar socio-economic characteristics $(X)$ can be compared if and only if the treatment assignment was random (Issahaku \& Abdulai, 2020).

The adoption of CSA was categorized into non-adoption (0), adoption of improved rice varieties only (1), adoption of irrigation only (2), and joint adoption (3). Therefore, adoption occurs if a rice farmer belongs to any of the three categories. Based on these classifications, MTE was applied to estimate the effects of each stage of adoption on rice gross income and risk exposure, setting non-adoption as a comparison group. According to Deb and Trivedi (2006a), the MTE has been specified with a latent indicator structure to allow for idiosyncratic influences on treatment choices of rice farmers to affect the outcomes variables. To the authors, this makes the model a distinction between selection on unobservable and selection on observables. The MTE indicator assumed to have multinomial logit distribution structure and the outcome function also assumed to follow a negative binomial distribution condition on treatment.

The common method of the econometric model for correcting selectivity bias effects has two segments based on the generation process of the treatment groups' indicators and outcome equations. A rice farmer decision to adopt CSA is the treatment and the rice gross income and risk exposure are the observed outcome measures. A rice farmer (i) makes a decision to adopt 
CSA from a set of four treatments $(\mathrm{t}=0,1,2.3)$. Representing $I U_{i t}^{*}$ which denotes the indirect utility function with the $t^{\text {th }}$ treatment, then the indirect utility function can be stated as:

$$
I U_{i t}^{*}=K_{i}^{\prime} \gamma_{t}+\sum_{t=1}^{t} \delta_{T K} \omega_{i k}+\tau_{i t}
$$

The $K_{i}$ represent the exogenous covariates, $\gamma_{t}$ represents the parameters to be estimated, and $\tau_{i t}$ is the error term which is an independently and identically distributed random shock. The indirect utility function $I U_{i t}^{*}$, comprises of the latent factors $\omega_{i k}$ which also encompass the unobservable characteristics general common to individual rice farmer (i) treatment of adoption stage and the outcomes such as improved rice varieties adoption only, irrigation adoption only, and joint adoption. It is assumed that $\omega_{i k}$ is independent to that of $\tau_{i t}$. Representing $t=0$ which denotes based group, the decision of a rice farmer not to adopt any of the CSAs, then the indirect utility function would set to zero for the based adoption; $I U_{i t}^{*}=0$. As $\omega_{i k}$ is unobservable, the binary variables $b_{t}$ were represented for the observed treatment decision to adopt the CSA option available to rice farmers. The $b_{t}$ follow the mixed multinomial logit pattern structure $b_{i}=\left(b_{i 1}, b_{12} \ldots \ldots . d_{1 t}\right)$. Therefore, the probability function for a rice farmer decision to adopt CSAs by a latent structure multinomial logit can be model as:

$$
\operatorname{Pr}\left(\frac{b_{i}}{K_{i}, \omega_{i}}\right)=\frac{\exp \left(K_{i}^{\prime} \gamma+\omega_{i t}\right)}{1+\sum_{k=1}^{t} \exp \left(K_{i}^{\prime} \gamma_{k}+\omega_{i t}\right)}
$$

Where $t=0,1,2,3, \& 4$.

The outcome equations (rice gross income and downstream risk exposure) can be expressed as:

$$
E\left(\frac{y_{i}}{b_{i}, k_{i}, \omega_{i}}\right)=\exp \left\{x_{i}^{\prime} \beta+\sum_{t=1}^{T} \quad \alpha_{t} b_{i t}+\sum_{t=1}^{T} \quad \pi_{t} \omega_{i t}\right\}
$$

The $x_{i}$ is the set of all exogenous covariates within $k_{i}$ with the associated parameter vector $\beta_{i}$, and $\alpha_{i}$, are the treatment coefficients relative to the based group of no direct adoption of 
CSAs efforts. The $E\left(y_{i}\right)$ is a function of each latent factors $\omega_{i t}$ when the outcome variables are linked to unobservable effects which might have direct and/or indirect influence of a rice farmer decision to adopt CSAs. The loading factor coefficients $\left(\pi_{t}\right)$ are estimated each effect (impact) of CSAs option on rice gross income and risk exposure.

This study used an endogenous multinomial treatment effect model proposed by Deb and Trivedi (2006a \& 2006b), accounting for selection on unobservable and continuous outcome variables. The treatment variables are adoption of CSAs and the outcome measure are rice gross income and risk exposure (skewness). The maximum simulated likelihood technique was used based on the joint distribution of the outcome and treatment variables. Similarly, 1000 Halton draws (Deb \& Trivedi, 2006a; \& 2006b) to ensure that maximization of the simulated log likelihood is equivalent to maximizing the log likelihood, yielding estimates that are consistent and asymptotically normal. To correct for heteroscedasticity problems, the robustness standard error was conducted to account for uncertainty from the finite simulation draws (McFadden \& Train, 2000).

In addition, when estimating a two-stage model like MTE, model identification is paramount. Therefore, setting a variable to identify the selection and outcome functions is very critical. This variable used for identification purposes is called an instrument. The instrumental variable was included in the multinomial logit selection function but excluded in the outcome functions (Di Falco \& Chavas, 2009; Kassie et al., 2014; Khonje et al., 2018; Issahaku \& Abdulai, 2019). That is, the instrument should have an effect on the selection function but not the outcome functions (rice gross income and risk exposure). To achieve this condition, the study used the land tenure system as an instrument. Following Di Falco et al. (2011), a simple falsification test was performed to assess the validity of the instrument. The study employed ordered probit in the first stage and OLS in the second estimations. The study established that the selection instrument was valid as it jointly influences farmers' adoption decision of CSA but not the rice gross income and risk exposure (see Table B). Hence, the land tenure system was excluded from the estimation functions for rice gross income and risk exposure.

Table A. Test of validity of an instrument to identify the Multinomial Treatment Effect model

\begin{tabular}{l|c|c}
\hline Variable & Gross income & Skewness of yield \\
\hline Land tenure system & $-0.042(0.138)$ & $-.0158(0.032)$ \\
\hline Constant & $7.032 * * *(0.130)$ & $5.840 * * *(0.030)$ \\
\hline$F$-test on instrument & $0.09(\mathrm{p}=0.763)$ & $0.25(\mathrm{p}=0.617)$ \\
\hline
\end{tabular}

Standard errors in parentheses. The values in the square bracket indicate the $p$-values of the $F$-test indicating the validity of the instruments used to identify the MTE model. 


\section{Results and Discussion}

\subsection{Descriptive Statistics and Variables Descriptions}

The descriptive statistics and measurements of the variables used in the econometric model are presented in Table B. Beginning with the response (dependent) variables, 18.6\%, 30.2\%, and $28.7 \%$ of the rice farmers adopted improved rice variety only, irrigation only, and both improved rice varieties and irrigation jointly respectively. However, $22.5 \%$ of the rice farmers were not able to adopt any of the two climate-smart agricultural practices in the study area.

Moving to the descriptive statistics of the independent variables, the results revealed that $83.2 \%$ of the rice farmers were males. The average rice farmer was about 38 years old with about 4 years of formal schooling. About $65.2 \%$ of the farmers were into rice cultivation for commercial reason. The average experience of a rice farmer in the cultivation of the commodity was approximately 12 years, with the rice farmers commuting an average distance of $7 \mathrm{~km}$ to the nearest input market. Also, the results revealed that an average rice farmer was able to apply about 5 bags $(250 \mathrm{~kg})$ of chemical fertilizers per acre. Social capital is very important for rice cultivation technologies uptake and subsequent adoption. The results revealed that an average farmer had spent 7 years in a farmer group (proxied in this study as social capital). About $26 \%$ of the rice farmers were into off-farm income generation activities. The average household size of a rice farmer was about 9 , comprising both males and females. Among the rice farmers, about $62 \%$ of them were having livestock as other sources of livelihood. A small proportion (11.8\%) of the rice farmers had access to production credit and received an average of 3.4 extension visits per year. Also, the average per acre gross income per farmer was recorded as GHS 1,637.43, resulting from an average per acre yield of $1,246.47 \mathrm{~kg}$.

Downstream risk exposure was contextualized in this study to mean how rice farmers were exposed to risk due to climate change which might lead to failure in farm outcomes. The predicted value of the third moment of computing risk exposure (skewness of rice yield) from the yield of rice had a mean value of 348.26. This indicates that the average rice farmer's exposure to failure in the crop production due to climatic stress was about $28 \%$ (computed as a ratio of the skewness of rice yield to the average per acre yield, $\left(\frac{348.26}{1246.47} * 100=0.279\right)$. In other words, without the adoption of the CSA practices, rice farmers would have experienced about $72 \%$ of crop failure in the study area. 
Table B. Descriptive Statistics of the rice

\begin{tabular}{lcccc}
\hline Variable & Mean & Std. Dev. & Min & Max \\
\hline Education (years) & 4.03 & 5.11 & 0 & 27 \\
Commercialization drive (1/0) & 0.65 & 0.48 & 0 & 1 \\
Experience (years) & 11.72 & 7.66 & 1 & 40 \\
Farm distance to market (km) & 6.69 & 4.92 & 1 & 50 \\
Quantity of fertilizers (bags(50kg)) & 5.11 & 37.58 & 0 & 850 \\
Social capital (number years in a farmer group) & 7.00 & 4.19 & 1 & 25 \\
Farm size (acres) & 2.42 & 3.63 & .25 & 60 \\
Off farm activity (1/0) & 0.26 & 0.44 & 0 & 1 \\
Age (years) & 38.49 & 10.70 & 15 & 75 \\
Sex (1/0) & 0.83 & 0.37 & 0 & 1 \\
House size (number of people per household) & 9.35 & 6.23 & 1 & 50 \\
Livestock (1/0) & 0.67 & 0.47 & 0 & 1 \\
Credit (1/0) & 0.12 & 0.32 & 0 & 1 \\
Extent of extension service (no. of times per year) & 3.40 & 5.34 & 0 & 35 \\
Rice revenue (per acre) & 1637.43 & 1343.06 & 0 & 6300 \\
Non-adoption (0) & 0.23 & - & - & - \\
Improved rice varieties only (1) & 0.19 & - & - & - \\
Irrigation only (3) & 0.302 & - & - & - \\
\hline Joint adoption (4) & 0.287 & - & - & - \\
\hline Rice yield (Kg) & 1246.47 & 669.65 & 42 & 3360 \\
\hline Risk exposure & 348.26 & 76.54 & 142.90 & 536.60 \\
\hline & & & & 1 \\
\hline
\end{tabular}

Note: $84 \mathrm{~kg}$ is equivalent to 1 bag of paddy rice; (1) Yes; (0) No.

Source: Field data estimates, 2021.

3.2 Drivers of Adoption of CSA (Improved Seeds and Irrigation) Practices Among Rice Farmers

The multinomial results of the first stage are presented in Table C. the Wald $\mathrm{Ch}^{2}$ (47) test was estimated to be $1,396.17\left(\mathrm{Pr} .>\mathrm{Chi}^{2}=0.0000\right)$ which is highly statistically significant at $1 \%$ significance level. The significance of the Wald $\mathrm{Chi}^{2}$ led to the rejection of the null hypothesis that estimated coefficients are jointly equal zero. That is the model is best fit for the analysis.

The results indicate that the age of a rice farmer has a negative coefficient and significant 
effects on the adoption of improved rice varieties only as well as irrigation only at $1 \%$ and $5 \%$ significance level respectively. This signifies that an increase in age of a rice farmer leads to a decrease in the likelihood to adopt CSA practices. Issahaku and Abdulai (2019) had similar results in their study of agricultural productivity and risk exposure in relation to adoption of climate-smart practices in Ghana. Many scholars have found the age of farmers to have an inverse relationship to enhanced agricultural technologies adoption (Gebrehiwot \& Van Der Veen 2013; Addisu et al. 2016; Maguza-Tembo et al. 2017; Asrat \& Simane, 2018). However, Atinkut and Mebrat (2016) found the age of farmers to have positive association with farmers' decision to adopt enhanced agricultural technologies.

The parametric results show that educational attainment of rice farmers in the study area found to have positive coefficient and a statistically significant effect on joint adoption of improved rice varieties and irrigation at $1 \%$ significance level. The positive effect of farmers educational level in enhancing agricultural technologies adoption has been well established in literature (Gebrehiwot \& Van Der Veen, 2013; Teklewold, Kassie \& Shiferaw, 2013; Addisu et al., 2016; Asrat \& Simane, 2018; Dung et al., 2018; Fadina \& Barjolle, 2018). According to Dung (2020), the low level of education of farmers affects their ability to obtain and process technical information which enhances the best combination of technologies to enhance agricultural production and productivity.

Household size of rice farmers has a negative coefficient which is having a significant effect on adoption of irrigation only at 5\% significance level. This implies that less household members are less likely to adopt irrigation as CSA practice. Smaller household size means poor family labour force, hence poor adoption of irrigation as irrigation is labour intensive. Awotide, Karimov and Diagne (2016) found household size to have a negative effect on lowland rice production among farm households in Nigeria. However, many studies found positive correlation between household size and adoption of enhanced agricultural technologies (Abdulai et al. 2011; Di Falco \& Veronesi 2013; Issahaku \& Abdulai, 2019; FARA, 2020). The results further revealed that livestock have a negative-significant effect on adoption of irrigation only and joint adoption both at $1 \%$ significance level respectively. This indicates that rice farmers without livestock are less likely to adopt CSA practices. Ownership of livestock is an indicator of wealth which can boost farmers' morale to invest in CSA to enhance sustainability of food systems production. This finding contradicts Issahaku and Abdulai (2019) that livestock have a positive effect on adoption of climate-smart technologies in Ghana.

Experience in rice farming is found to have a positive significant effect on adoption of improved rice varieties only, irrigation only, and joint adoption at $1 \%$ significance level respectively. Rice farmers with many years in rice production have the potential to observe climate change patterns and ability to adopt CSA to cope with the changes. This is consistent with the findings of Azumah et al. (2017) which indicated that experienced farmers have a high probability to adopt climate-smart coping mechanisms. Off-farm activity is found to have positive significant effect on the adoption of improved rice varieties only at $5 \%$ significance level but negative-significant effect on adoption of irrigation only at $5 \%$ level. The plausible explanation of such findings is that a rice farmer who participates in off-farm activities is more 
likely to adopt improved rice varieties but less likely to practice irrigation as CSA. There has been a negative association of off-farm activities to CSA practices (Issahaku \& Abdulai, 2019) while others found off-farm activity to have positive association with adoption of CSA (Teklewold, Kassie, \& Shiferaw, 2013; Addisu et al. 2016; Asrat \& Simane, 2018).

Farm size has a negative significant effect on joint adoption only (at 1\% significance level). A rice farmer with a small farm area for rice cultivation is less likely to adopt improved rice varieties and irrigation jointly. Agricultural production is a risky venture due to uncertainty and high production and information costs in relation to enhanced technologies adoption decisions. This prevents rice farmers with small farmland areas to adopt CSA (Dung et al., 2018 \& Dung, 2020). It has been established that holders of larger farmlands are more interested in investing in CSA compared to small farmland holders (Teklewold, Kassie, \& Shiferaw 2013; Atinkut \& Mebrat 2016; Fadina \& Barjolle 2018). Social capital's role in CSA adoption cannot be overlooked. From the study, it has been revealed that social capital has a positive significant effect on joint adoption of CSA at $1 \%$ significance level. This means that when there is an increase the number of farmers groups a farmer belongs, adoption of CSA will increase. This finding is backed by (Isham, 2002; Bandiera \& Rasul, 2006; Wollni, Lee, \& Thies, 2010; Kassie et al. 2013; Dung, 2020) as they found social capital to have positive influence on adoption of CSA.

Access to production credit is demonstrated to have positive coefficient and significant effect on adoption of improved rice varieties only and a negative significant effect on irrigation only at 5\% significance level respectively. Dung (2020) and Abdul-Rahaman et al. (2021) found that access to production credit has positive effects on farmers' weather risk management, adoption of soil and water conservation mechanisms and enhanced rice varieties in Vietnam and Ghana respectively. Also, Kassie et al. (2015) and Mulwa et al. (2017) agreed that access to production credit is a key determinant of farmers' decision to adopt CSA. Nevertheless, Onumadu and Osahon (2014), Gyinadu, Bakang, and Osei (2015), and Mmbando and Baiyegunhi (2016) lamented that inadequate farm credit hinders adoption of CSA.

Access to agricultural extension services found to have positive coefficients and significant effects on adoption of improved rice varieties only and joint adoption at $1 \%$ and 5\% significance level respectively. This simply means that access to agricultural extension services by a farmer will increase his/her probability of adoption decision to CSA. Issahaku and Abdulai (2019) and Dung (2020) found that extension services provided to farmers increases their probability of adoption of CSA. Agricultural extension service personnel provide the necessary climate change related information and the need to adopt CSA to cope with the changing climate. The provision of climate information and technical services to farmers have the potential to influence farmers' behaviour to adopt CSA practices. The last indicator is land tenure which found positive and negative coefficients as well as have significant effects on adoption, improved rice varieties only and irrigation only at $10 \%$ significance level respectively. Studies have found that land tenure systems exerted positive and negative effects on adoption of CSA (IOB, 2011; Lawry et al., 2014; Higgins et al., 2017; Dung, 2020). 
Table C. Drivers of adoption of Climate Smart Agriculture: Multinomial logit selection model

\begin{tabular}{|c|c|c|c|c|c|c|}
\hline \multirow[t]{2}{*}{ Factor } & \multicolumn{2}{|c|}{ Improved varieties only } & \multicolumn{2}{|c|}{ Irrigation only } & \multicolumn{2}{|c|}{ Joint adoption } \\
\hline & Coefficient & Std. Err. & Coefficient & Std. Err. & Coefficient & Std. Err. \\
\hline Age & $-0.107 * * *$ & 0.033 & $-0.060 * *$ & 0.031 & -0.021 & 0.028 \\
\hline Sex & 0.974 & 0.807 & 0.230 & 0.646 & 0.735 & 0.678 \\
\hline Education & 0.026 & 0.056 & 0.072 & 0.048 & $0.135 * * *$ & 0.050 \\
\hline $\mathrm{RC}$ & -0.401 & 0.608 & 0.562 & 0.553 & 0.862 & 0.579 \\
\hline Household size & -0.005 & 0.039 & $-0.092 * *$ & 0.047 & 0.001 & 0.037 \\
\hline Livestock & -0.604 & 0.795 & $-2.380 * * *$ & 0.622 & $-1.824 * * *$ & 0.656 \\
\hline Experience & $0.125 * * *$ & 0.045 & $0.220 * * *$ & 0.043 & $0.238 * * *$ & 0.043 \\
\hline Off- farm activity & $1.257 * *$ & 0.576 & $-1.605^{* *}$ & 0.666 & -0.760 & 0.624 \\
\hline Farm size & 0.136 & 0.113 & 0.152 & 0.116 & $-0.874 * * *$ & 0.193 \\
\hline Social capital & 0.037 & 0.066 & -0.050 & 0.071 & $-0.352 * * *$ & 0.089 \\
\hline Credit & $1.311 * *$ & 0.600 & $-1.650 * *$ & 0.712 & -0.421 & 0.631 \\
\hline Extension & $0.228 * * *$ & 0.060 & 0.007 & 0.072 & $0.133 * *$ & 0.061 \\
\hline Land tenure & $1.690 *$ & 0.971 & $-1.522 *$ & 0.835 & -0.847 & 0.815 \\
\hline _cons & -0.079 & 1.343 & $2.341^{*}$ & 1.226 & 1.399 & 1.234 \\
\hline \multicolumn{7}{|l|}{ Model summary } \\
\hline Wald chi2(47) = & \multicolumn{6}{|c|}{1396.17} \\
\hline Prob > chi 2 & \multicolumn{6}{|c|}{0.0000} \\
\hline Log likelihood $=$ & \multicolumn{6}{|c|}{-12.769241} \\
\hline
\end{tabular}

Notes: category1 is the control group (non-adoption)

Source: Field data estimates using STATA, 2021.

3.3 Effect of Adoption of CSA Practices (Improved Seeds and Irrigation) on Gross Income and Downstream Risk Exposure

Table D presents the results of the effect of adoption of improved rice seed and irrigation on rice income and risk exposure. The $K_{1}$ (improved rice varieties only), $K_{2}$ (irrigation only), and $K_{3}$ (joint adoption) denote the selectivity terms which assessed the effects arising from unobserved characteristics. The selectivity outcomes all have statistically significant effects on both rice income and risk exposure functions. This implies that there was evidence of selectivity bias effects, justifying the use of the multinomial treatment effect model. Using OLS for the estimation would have produced biased and inconsistent estimates. 
The estimated results demonstrated that adoption of improved rice varieties, irrigation, and joint adoption have posited positive effects on rice income and risk exposure. The implications of such findings are that adoption of improved rice varieties, irrigation, and joint adoption lead to higher rice income and reduction of farmers' exposure to risk in rice production. Also, the significant effect of joint adoption signifies that adoption of rice varieties and irrigation are complementary. The changing climate continues to expose farmers to production risk which also reduces rice income, making farmers vulnerable. Adoption of climate change mechanisms like improved rice varieties and irrigation reduces farmers' exposure to climate risk and at the same time increases rice income (revenue). Issahaku and Abdulai (2020) also found that adoption of crop choice and soil and water conservation translates to higher crop revenue and reduction of production risk in the face of climate change in Ghana. Other researchers like Tecklewold et al. (2013) in Ethiopia; Manda et al. (2015), and Ng'ombe et al. (2017) both in Zambia have found similar results. Moving forward, Kassie et al. (2014) findings demonstrated that farm households in Malawi who adopted on-farm climate change mechanisms minimizes farmers' exposure to downside risk which in turn reduces the risk of agricultural production failure.

In terms of socio-economic factors, education was found to have a positive significant effect on both rice income and risk exposure at $5 \%$ and $1 \%$ respectively. This finding suggests that an increase of a farmer level of education by one year will lead to high rice income and reduction of production risk in the presence of the changing climate. Education broadens farmers' knowledge and skills in farming as well as adoption of climate change mechanisms. It helps them to combine the right quantity of inputs to minimize cost in order to maximize output per hectare. As farmers learn how to use the right quantity mix for rice production, they are less exposed to production risk in the changing climate.

Commercialization drive had a positive significant effect on both rice income and risk exposure at $1 \%$ respectively. The positive significant effect of commercialization drive on rice income and risk exposure means that farmers who are into rice production on commercial purpose turn to achieve more rice income and less risky in rice production. Farmers who take rice production as a business (profit making) adopt climate change mechanisms including improved rice varieties and irrigation to attain much more rice output and income. As farmers' rice income rises, it turns in reducing them to climate change vulnerability. Rice production failure is high when climate change and variability is high in a particular year. Adoption of climate change mechanisms have the potential to reduce production risk of rice, hence, increase rice income per hectare.

In addition, experience in rice production was found to have a positive significant effect on rice income and risk exposure at $10 \%$ and $1 \%$ respectively. The economic intuitions of such findings are that more years in rice production translate to high revenue, which contribute to reduction of crop failure farmers might face. Farm distance to market was found to have a negative significant effect on only risk exposure at $1 \%$ level. That is, longer farms deny farmers access to markets which in turn affect farmers ability to adopt climate change mechanisms. This lowers rice production and productivity as well as revenue. As farmers fail to adopt climate change mechanisms, the risk of crop failure will be high and rice revenue will be 
declining at the same time. Quantity of chemical fertilizer applied per hectare found to have a negative effect on rice income only which was statistically significant at $5 \%$. This implies that farmers who apply less quantity of chemical fertilizer required for a hectare are likely to have reduced rice income due to poor yields. Climate change and pressure on the land reduces soil fertility. To increase soil fertility to maximize rice output and income, applying the right quantity of fertilizers have become the option. Even though farmers are faced with financial constraint, they can reduce farm size for cultivation and purchase more fertilizers and apply the right quantity needed per hectare to achieve more rice output and income in the presence of the changing environment.

Social capital (years of farmer group membership) plays a critical role in technology adoption and agricultural productivity. The study found that social capital has a positive significant effect on only rice income at $1 \%$ level. Meaning farmers' who had stayed longer in their respective farmer groups had the potential to have higher incomes. Also, farm size was found to have a negative significant effect on rice income and risk exposure (at 5\% and $1 \%$ levels) respectively. The implication is that smaller farm sizes reduced rice farmers' income but had the tendency to increase farmers' risk of crop failure.

Table D. Effect of adoption of Climate Smart Agriculture on rice gross income and downstream risk exposure

\begin{tabular}{lcclc}
\hline Variable & \multicolumn{2}{c}{ Rice income } & \multicolumn{2}{c}{ Downstream risk exposure } \\
\cline { 2 - 5 } & Coef. & Std. Err. & Coef. & Std. Err. \\
\hline Treatment factors & & & & \\
Improved varieties only & $0.278^{*}$ & 0.148 & $0.090^{* * *}$ & 0.024 \\
Irrigation only & $1.739^{* * *}$ & 0.139 & $0.195^{* * *}$ & 0.024 \\
Joint adoption & $1.514^{* * *}$ & 0.146 & $0.081^{* * * *}$ & 0.024 \\
Socio-economic factors & & & & \\
Education & $0.018^{* *}$ & 0.008 & $0.012^{* * * *}$ & 0.001 \\
Commercialization drive & $0.405^{* * *}$ & 0.094 & $0.235^{* * *}$ & 0.015 \\
Experience & $0.011^{*}$ & 0.006 & $0.011^{* * * *}$ & 0.001 \\
Farm distance to market & -0.002 & 0.012 & $-0.012^{* * *}$ & 0.002 \\
Fertilizer & $-0.008^{* *}$ & 0.004 & 0.0001 & 0.001 \\
Social capital & $0.039^{* * *}$ & 0.012 & 0.0001 & 0.002 \\
Farm size & $-0.041^{* *}$ & 0.019 & $-0.018^{* * * *}$ & 0.003 \\
Off farm activity & -0.120 & 0.112 & -0.012 & 0.018 \\
_cons & $5.429 * * *$ & 0.185 & $5.506^{* * * *}$ & 0.028 \\
\hline Selectivity & & & &
\end{tabular}

Selectivity diagnosis 
/Insigma

K(categoryl)

K(category2)

K(category3)

sigma
$-0.427 * * *$

$0.198 * * *$

$-0.262 * * *$

0.020

$0.653 * * *$
0.056

0.074

0.071

0.071

0.036
$-2.753 * * *$

0.294

0.016

0.018

0.018

0.019

Source: Field data estimates using STATA, 2021.

\section{Conclusions and Policy Implications}

Globally, the demand for rice is on a surge, with countries like Ghana having an annual production deficit of more than 40 percent. Cultivation of the commodity continues to be affected by several socio-economic and environmental factors. The effect of climate change on agricultural production systems have been well documented, justifying the need to promote climate smart agricultural (CSA) practices among farmers especially in rural Africa.

We note the lack of empirical literature that highlights the nexus between the adoption of CSA practices and the attendant implication on gross income of rice farmers, and the risk characterization of farmers. Following this, a Multinomial Treatment Effect (MTE) model was fitted using primary data collected from 543 rice farmers in Ghana to examine factors that drive rice farmers to adopt improved rice varieties and irrigation as well as joint adoption (of improved rice varieties and irrigation) in northern Ghana. The study further explored the effect of individual adoption of the CSA technologies on gross income of rice farmers, and a reduction of downstream risk in the face of climate change.

The results demonstrate that experience, off-farm activity, production credit, agricultural extension services, and land tenure increases rice farmers' probability of adopting improved rice varieties, while age (younger farmers) decreases the probability of adopting improved rice varieties. Experience in rice production increases the probability of adopting irrigation while age, household size, livestock ownership, off-farm activity, production credit, and land tenure potentially decreases the adoption of irrigation as a CSA practice. Also, education, experience, and agricultural extension service provision increase rice farmers' probability of joint adoption of improved rice seeds and irrigation. Meanwhile, livestock ownership, farm size, and social capital decrease rice farmers' probability of joint adoption of CSA practices. Furthermore, the study concludes that the single adoption improved rice seeds and irrigation as well as joint adoption significantly had positive effects on income and a reduction in rice farmers' risk exposure. Socioeconomic factors such as education, commercialization, experience, and social capital significantly increase income and potentially reduce rice farmers' exposure to risk in rice production; while less quantity of fertilizer applied per acre and small farm size decrease gross income and exposes farmers to risk in rice production.

The study further concludes that the average rice farmer's exposure to failure in the crop production due to climatic stress is about $13 \%$ (computed as a ratio of the skewness of rice yield to the average per acre yield. In other words, without the adoption of the CSA practices, rice farmers would have experienced about 87 percent of crop failure in the study area. By 
this, it can cogently be argued that the adoption of CSA practices plays a critical role in fighting food and nutrition security among smallholders in developing countries and must be given some credence. For policy consideration, climate smart production mechanisms such as the use of improved varieties and irrigation should be promoted by interventions that seek to support the rice sector. The government of Ghana should as a matter of priority, promote irrigation as part of the flagship planting for food and jobs (PFJ) policy together with the improved seeds supplied to rice farmers under the policy. Finally, socioeconomic factors that enhance the adoption of CSA practices, increase gross income while reducing downstream risk in rice production should be targeted by policymakers and project implementers.

\section{References}

Abdulai, A., \& Huffman, W. (2000). Structural adjustment and economic efficiency of rice farmers in northern Ghana. Economic Development and Cultural Change, 48(3), 503-520. https://doi.org/10.1086/452608

Abdulai, A., Owusu, V., \& Goetz, R. (2011). Land tenure arrangements and investment in land Improvement measures: theoretical and empirical analysis, Journal of Development Economics, 96, 66-78. https://doi.org/10.1016/j.jdeveco.2010.08.002

Abdul-Rahaman, A., Issahaku, G., \& Zereyesus, Y. A. (2021). Improved rice variety adoption and farm production efficiency: Accounting for unobservable selection bias and technology gaps among smallholder farmers in Ghana. Technology in Society, 64, 1-11. https://doi.org/10.1016/j.techsoc.2020.101471

Addisu, S., Fissha, G., Gediff, B., \& Asmelash, Y. (2016). Perception and adaptation models of climate change by the rural people of lake Tana Sub-Basin, Ethiopia. Environmental Systems, 5(7), 1-10. https://doi.org/10.1186/s40068-016-0059-0

Anuga, S. W., Gordon, C., Boon, E., \& Surugu, J. M. I. (2019). Determinants of Climate Smart Agriculture (CSA) Adoption among Smallholder Food Crop Farmers in the Techiman Municipality, Ghana. Ghana Journal of Geography, 11(1), 124-139.

Arouna, A., Lokossou, J. C., Wopereis, M. C. S., Bruce-Oliver, S., \& Roy-Macauley, H. (2017). Contribution of improved rice varieties to poverty reduction and food security in sub-Saharan Africa. Global Food Security, 14, 54-60. https://doi.org/10.1016/j.gfs.2017.03.001

Arunrat, N., Wang, C., Pumijumnong, N., Sereenonchai, S., \& Cai, W. (2017). Farmers' intention and decision to adapt to climate change: A case study in the Yom and Nan basins, Phichit province of Thailand. Journal of Cleaner Production, 143, 672-685. https://doi.org/10.1016/j.jclepro.2016.12.058

Asrat, P., \& Simane, B. (2018). Farmers' perception of climate change and adaptation strategies in the Dabus watershed, North-West Ethiopia. Ecological Processes, 7(7), 1-13. https://doi.org/10.1186/s13717-018-0118-8

Awotide, B. A., Awoyemi, T. T., Omonona, B. T., \& Diagne, A. (2016). 10 Impact of Improved Agricultural Technology Adoption on Sustainable Rice Productivity and Rural Farmers' Welfare in Nigeria. Inclusive Growth in Africa: Policies, Practice, and Lessons Learnt, 216-237. 
https://doi.org/10.1186/s40100-016-0047-8

Awotide, B. A., Karimov, A. A., \& Diagne, A. (2016). Agricultural technology adoption, commercialization and smallholder rice farmers' welfare in rural Nigeria. Agricultural and Food Economics volume, 4(3), 1-24. https://doi.org/10.1186/s40100-016-0047-8

Azumah, S. B., Donkoh, S. A., \& Ansah I. G. K. (2017). Contract farming and the adoption of climate change coping and adaptation strategies in the northern region of Ghana. Environment, Development and Sustainability, 19(6), 2275-2295. https://doi.org/10.1007/s10668-016-9854-z

Bandiera, O., \& Rasul, I. (2006). Social networks and technology adoption in Northern Mozambique. The Economic Journal, 116(514), 869-902. https://doi.org/10.1111/j.1468-0297.2006.01115.x

Cattaneo, M. D. (2010). Efficient semiparametric estimation of multi-valued treatment effects under ignorability. Journal of Econometrics, 155(2), 138-154. https://doi.org/10.1016/j.jeconom.2009.09.023

Chandio, A. A., \& Yuansheng, J. I. A. N. G. (2018). Determinants of adoption of improved rice varieties in northern Sindh, Pakistan. Rice Science, 25(2), 103-110. https://doi.org/10.1016/j.rsci.2017.10.003

De Silva, C. S., Weatherhead, E. K., Knox, J. W., \& Rodriguez-Diaz, J. A. (2007). Predicting the impacts of climate change-a case study of paddy irrigation water requirements in Sri Lanka. Agricultural and Water Management, 93(1-2), 19-29. https://doi.org/10.1016/j.agwat.2007.06.003

Deb, P., \& Trivedi, P. K. (2006a). Specification and simulated likelihood estimation of a non-normal treatment-outcome model with selection: Application to health care utilization. The Econometrics Journal, 9(2), 307-331. https://doi.org/10.1111/j.1368-423X.2006.00187.x

Deb, P., \&Trivedi, P. K. (2006b). Maximum simulated likelihood estimation of a negative binomial regression model with multinomial endogenous treatment. Stata Journal, 6(2), 246-255. https://doi.org/10.1177/1536867X0600600206

DeVellis, R. F. (2012). Scale development: Theory and applications. Los Angeles: Sage, 109-110.

Di Falco, S., \& Chavas, J.P. (2009). On crop biodiversity, risk exposure and food security in the highlands of Ethiopia, American Journal of Agricultural Economics, 91, 599-611. https://doi.org/10.1111/j.1467-8276.2009.01265.x

Di Falco, S., \& Veronesi, M. (2013). How can African agriculture adapt to climate change? A counterfactual analysis from Ethiopia, Land Economics, 89, 743-766.

Di Falco, S., \& Veronesi, M. (2014). Managing Environmental Risk in Presence of Climate Change: The Role of Adaptation in the Nile Basin of Ethiopia, Environmental and Resource Economics, 57(4), 553-577. https://doi.org/10.1007/s10640-013-9696-1

Di Falco, S., Veronesi, M., \& Yesuf, M. (2011). Does adaptation to climate change provide food security? A micro-perspective from Ethiopia. American Journal of Agricultural Economics, 93(3), 829-846. https://doi.org/10.1093/ajae/aar006

Djaman, K., Mel, V. C., Diop, L., Sow, A., El-Namaky, R., Manneh, B., \& Irmak, S. (2018). Effects of alternate wetting and drying irrigation regime and nitrogen fertilizer on yield and nitrogen use 
efficiency of irrigated rice in the Sahel. Water, 10(6), 711. https://doi.org/10.3390/w10060711

Donkoh, S. A., Ayambila, S., \& Abdulai, S. (2013). Technical efficiency of rice production at the Tono irrigation scheme in northern Ghana. American Journal of Experimental Agriculture, 3(1), 25-42. https://doi.org/10.9734/AJEA/2013/1448

Donkor, E., Matthews, N., \& Ogundeji, A. A. (2018). Efficiency of rice farming in ghana: Policy implications for rice sector development. African Development Review, 30(2), 149-161. https://doi.org/10.1111/1467-8268.12320

Durand-Morat, A., \& Chavez, E. C. (2020). International Rice Outlook International Rice Baseline Projections, 2019-2029. Arkansas Global Rice Economics Program.

Emmanuel, D., Owusu-Sekyere, E., Owusu, V., \& Jordaan, H. (2016). Impact of agricultural extension service on adoption of chemical fertilizer: Implications for rice productivity and development in Ghana. NJAS-Wageningen Journal of Life Sciences, 79, 41-49. https://doi.org/10.1016/j.njas.2016.10.002

Fadina, A. M. R., \& Barjolle. D. (2018). Farmers' adaptation strategies to climate change and their implications in the Zou Department of South Benin. Environments, 5(15), 1-17. https://doi.org/10.3390/environments5010015

FAO (2017). Climate Smart Agriculture Sourcebook (Available from: http://www.fao.org/climate-smart-agriculture-sourcebook/en/

FARA (2020). Book of Extended Abstracts. Biennial Climate Smart Agriculture Stakeholders Conference. Forum for Agricultural Research in Africa (FARA), Accra Ghana. PP.

Gebrehiwot, T., \& Van Der Veen, A. (2013). Farm-level adaptation to climate change: The case of farmers in the Ethiopian Highlands. Environmental Management, 52(1), 29-44. https://doi.org/10.1007/s00267-013-0039-3

George, D., \& Mallery, P. (2003). SPSS for Windows step by step - A simple guide and reference. 11.0 update. Boston: Allyn and Bacon.

Gyinadu, A., Bakang, J. E. A., \& Osei, C. K. (2015). Determinants of adoption of yam minisett technology in Ghana: A case study of yam farmers in the Kintampo North District of Ghana. Journal of Agricultural Economics, Extension and Rural Development, 3(7), 293-302.

Hasan, M. K., Desiere, S., D’Haese, M., \& Kumar, L. (2018). Impact of climate-smart agriculture adoption on the food security of coastal farmers in Bangladesh. Food Security, 10(4), 1073-1088. https://doi.org/10.1007/s12571-018-0824-1

Imbens, G. W., \& Wooldridge, J. M. (2009). Recent developments in the econometrics of program evaluation. Journal of Economic Literature, 47(1), 5-86. https://doi.org/10.1257/jel.47.1.5

International Food Policy Research Institute (IFPRI). (2020). Ghana's rice market. MoFA-IFPRI Market Brief 2. Washington, DC: International Food Policy Research Institute (IFPRI). https://doi.org/10.2499/p15738coll2.133697

Isham, J. (2002). The effect of social capital on fertilizer adoption: Evidence from rural Tanzania. 
Journal of African Economies, 11(1), 39-60. https://doi.org/10.1093/jae/11.1.39

Issahaku, G., \& Abdulai, A. (2019). Adoption of climate-smart practices and its impact on farm performance and risk exposure among smallholder farmers in Ghana. Australian Journal of Agricultural and Resource Economics, 64, 396-420. https://doi.org/10.1111/1467-8489.12357

Issahaku, G., \& Abdulai, A. (2020). Can Farm Households Improve Food and Nutrition Security through Adoption of Climate-smart Practices? Empirical Evidence from Northern Ghana. Applied Economic Perspectives and Policy, 42(3), 559-579. https://doi.org/10.1093/aepp/ppz002

Jumiyati, R. S. (2021). Increasing production and income of rice farming: Keywords of food security and poverty alleviation. Earth and Environmental Science. https://doi.org/10.1088/1755-1315/870/1/012021

Kangogo, D., Dentoni, D., \& Bijman, J. (2021). Adoption of climate-smart agriculture among smallholder farmers: Does farmer entrepreneurship matter? Land Use Policy https://doi.org/10.1016/j.landusepol.2021.105666

Kassie, M., Shiferaw, B., \& Muricho, G. (2011). Agricultural technology, crop income, and poverty alleviation in Uganda. World development, 39(10), 1784-1795. https://doi.org/10.1016/j.worlddev.2011.04.023

Kassie, M., Teklewold, H., Jaleta, M., Marenya, P., \& Erenstein, O. (2015). Understanding the adoption of a portfolio of sustainable intensification practices in Eastern and Southern Africa. Land Use Policy, 42(1), 400-411. https://doi.org/10.1016/j.landusepol.2014.08.016

Kassie, M., Teklewold, H., Marenya, P., Jaleta, M., \& Erenstein, O. (2014). Production Risk and food security under Alternative Technology Choices in Malawi: Application of Multinomial Endogenous Switching Regression, Journal of Agricultural Economics, 66(3), 640-659. https://doi.org/10.1111/1477-9552.12099

Khonje, M. G., Manda, J., Mkandawire, P., Tufa, A. H., \& Alene, A. D. (2018). Adoption and welfare impact of multiple agricultural technologies: evidence from eastern Zambia. Agricultural Economics, 49(5), 599-609. https://doi.org/10.1111/agec.12445

Langerwisch, F., Václavík, T., von Bloh, W., Vetter, T., \& Thonicke, K. (2017). Combined effects of climate and land-use change on the provision of ecosystem services in rice agro-ecosystems. Environmental Research Letters, 13(1), 015003. https://doi.org/10.1088/1748-9326/aa954d

Lipper, L., Thornton, P., Campbell, B. M., Baedeker, T., Braimoh, A., Bwalya, M., \& Torquebiau, E. F. (2014). Climate-smart agriculture for food security. Nature climate change, 4(12),1068-1072. https://doi.org/10.1038/nclimate2437

Lv, Z., Zhu, Y., Liu, X., Ye, H., Tian, Y., \& Li, F. (2018). Climate change impacts on regional rice production in China. Climatic change, 147(3-4), 523-537. https://doi.org/10.1007/s10584-018-2151-0

Maguza-Tembo, F., Mangison, J., Edris, A. K., \& Kenamu. E. (2017). Determinants of adoption of multiple climate change adaptation strategies in Southern Malawi: An ordered probit analysis. Journal of Development and Agricultural Economics, 9(1), 1-7. https://doi.org/10.5897/JDAE2016.0753 
Manda, J., Alene, A. D., Gardebroek, C., Kassie, M., \& Tembo, G. (2015). Adoption and Impacts of Sustainable Agricultural Practices on Maize Yields and Incomes: Evidence from Rural Zambia. Journal of Agricultural Economics, 1-25. https://doi.org/10.1111/1477-9552.12127

McFadden, D., \& Train, K. (2000). Mixed MNL models for discrete response. Journal of applied Econometrics, $15(5)$,

447-470. https://doi.org/10.1002/1099-1255(200009/10)15:5<447::AID-JAE570>3.0.CO;2-1

Mmbando, F. E., \& Baiyegunhi, L. J. S. (2016). Socioeconomic and institutional factors influencing adoption of improved maize varieties in Hai District, Tanzania. Journal of Human Ecology, 53(1), 49-56. https://doi.org/10.1080/09709274.2016.11906955

MoFA (2018). Agricultural Sector Annual Progress Report. MoFA. Accra, Ghana.

Mujeyi, A., Mudhara, M., \& Mutenje, M. J. (2020). Adoption determinants of multiple climate smart agricultural technologies in Zimbabwe: Considerations for scaling-up and out. African Journal of $\begin{array}{llll}\text { Science, Technology, Innovation and } & \text { 735-746. }\end{array}$ https://doi.org/10.1080/20421338.2019.1694780

Mulwa, C., Marenya, P., Rahut, D. B., \& Kassie, M. (2017). Response to climate risks among smallholder farmers in Malawi: A multivariate probit assessment of the role of information, household demographics, and farm characteristics. Climate Risk Management, 16(1), 208-221. https://doi.org/10.1016/j.crm.2017.01.002

Nakano, Y., Tsusaka, T. W., Aida, T., \& Pede, V. O. (2018). Is farmer-to-farmer extension effective? The impact of training on technology adoption and rice farming productivity in Tanzania. World Development, 105, 336-351. https://doi.org/10.1016/j.worlddev.2017.12.013

Ng'ombe, J. N., Kalinda, T. H., \& Tembo, G. (2017). Does adoption of conservation farming practices result in increased crop revenue? Evidence from Zambia. Agrekon, 56(2), 205-221. https://doi.org/10.1080/03031853.2017.1312467

Nonvide, G. M. A. (2017). Effect of adoption of irrigation on rice yield in the municipality of Malanville, Benin. African Development Review, 29(S2), 109-120. https://doi.org/10.1111/1467-8268.12266

Palombi, L., \& Sessa, R. (2013). Climate-smart agriculture: sourcebook. Climate-smart agriculture: sourcebook.

Rosenbaum, P. R., \& Rubin, D. B. (1983). Assessing sensitivity to an unobserved binary covariate in an observational study with binary outcome. Journal of the Royal Statistical Society: Series B (Methodological), 45(2), 212-218. https://doi.org/10.1111/j.2517-6161.1983.tb01242.x

Scoones, I., \& Thompson, J. (2011). The Politics of Seed in Africa's Green Revolution: Alternative Narratives and Competing Pathways. IDS Bulletin, 42(4), 1-23. https://doi.org/10.1111/j.1759-5436.2011.00232.x

Slovin, E. (1960). Slovin's formula for sampling technique. Retrieved on February, 3, 2021.

Taylor, M. (2018). Climate-smart agriculture: what is it good for? The Journal of Peasant Studies, 45(1), 
89-107. https://doi.org/10.1080/03066150.2017.1312355

Teklewold, H., Kassie, M., \& Shiferaw, B. (2013). Adoption of multiple sustainable agricultural practices in rural Ethiopia. Journal of Agricultural Economics, 64(3), 597-623. https://doi.org/10.1111/1477-9552.12011

Teklewold, H., Kassie, M., Shiferaw, B., \& Kohlin, G. (2013). Cropping system diversification, conservation tillage and modern seed adoption in Ethiopia: Impacts on household income, agrochemical use and demand for labor. Ecological Economics, 93, 85-93. https://doi.org/10.1016/j.ecolecon.2013.05.002

Teklewold, H., Mekonnen, A., Kohlin, G., \& Di Falco, S. (2017). Does Adoption of Multiple Climate-smart Practices Improve Farmers Climate Resilience? Empirical Evidence from The Nile Basin of Ethiopia. Climate Change Economics, 8(1), 1750001. https://doi.org/10.1142/S2010007817500014

Van Oort, P. A., \& Zwart, S. J. (2018). Impacts of climate change on rice production in Africa and causes of simulated yield changes. Global Change Biology, 24(3), 1029-1045. https://doi.org/10.1111/gcb.13967

Villano, R., Bravo-Ureta, B., Solís, D., \& Fleming, E. (2015). Modern rice technologies and productivity in the Philippines: Disentangling technology from managerial gaps. Journal of Agricultural Economics, 66(1), 129-154. https://doi.org/10.1111/1477-9552.12081

Wollni, M., Lee, D. R., \& Thies, J. E. (2010). Conservation agriculture, organic marketing, and collective action in the Honduran hillsides. Agricultural Economics, 41(3-4), 373-384. https://doi.org/10.1111/j.1574-0862.2010.00445.x

Wongchalee, P., Arikit, S., Ruanjaichon, V., Vannavichit, A., \& Malumpong, C. (2015). The impact of high temperature on seed set at reproductive stages between heat-tolerant vs non-tolerant lines and the segregation analysis of seed set trait in the F2 population. Proceedings of 53rd Kasetsart University Annual Conference, 3-6 February 2015, Kasetsart University, Thailand. Smart Agriculture "The Future of Thailand". Plants, Animals, Veterinary Medicine, Fisheries, Agricultural Extension and Home Economics. Kasetsart University, 17-24.

World Bank (2011). Climate-Smart Agriculture: Increased Productivity and Food Security, Enhanced Resilience and Reduced Carbon Emissions for Sustainable Development-Opportunities and Challenges for a Converging Agenda: Country Examples. World Bank, Washington, DC.

World Bank, FAO \& IFAD (2015). Gender in Climate-Smart Agriculture: Module 18 for Gender in Agriculture Sourcebook, World Bank, FAO and IFAD, Washington, DC.

Zakaria, A., Azumah, S. B., Appiah-Twumasi, M., \& Dagunga, G. (2020). Adoption of climate-smart agricultural practices among farm households in Ghana: The role of farmer participation in training programmes. Technology in Society, 63, 01338. https://doi.org/10.1016/j.techsoc.2020.101338

Zhang, Z., Li, J., Pan, Y., Li, J., Shi, H., Zeng, Y., \& Li, Z. (2017). Natural variation in CTB4a enhances rice adaptation to cold habitats. Nature Communications, 8(1), 1-13. https://doi.org/10.1038/ncomms14788 


\section{Copyright Disclaimer}

Copyright for this article is retained by the author(s), with first publication rights granted to the journal.

This is an open-access article distributed under the terms and conditions of the Creative Commons Attribution license (http://creativecommons.org/licenses/by/4.0/). 